\title{
Observing Justice at Guantánamo Bay: Human Rights NGOs and Trial Monitoring at the US Military Commissions
}

\author{
Kjersti Lohne ${ }^{1}$ (D)
}

Accepted: 18 March 2021/ Published online: 22 May 2021

(C) The Author(s) 2021, corrected publication 2021

\begin{abstract}
The article critically considers the role of NGOs at the US naval base in Guantánamo Bay, Cuba. On the basis of observation of pre-trial hearings for the case against Khalid Sheik Mohammed et al. - those allegedly responsible for the September 11 attacksthe article analyses NGOs as trial monitors of the US military commissions set up to deal with 'alien unprivileged enemy belligerents'. In spite of continued efforts by human rights NGOs and incremental improvements in the military commissions' institutional arrangements and practice, the article shows how NGOs have become so much a part of the everyday operation of justice at 'Gitmo' that they legitimate the military commissions' claim to be delivering fair and transparent justice.
\end{abstract}

Keywords Counter-terrorism $\cdot$ Fair trial rights $\cdot$ Human rights monitoring $\cdot$ Military commissions $\cdot$ September $11 \cdot$ Torture

\section{Introduction}

Whether or not nongovernmental organizations (NGOs) should engage with antagonistic actors, institutions, and states is a familiar and ever-present issue for humanitarian practitioners and scholars. As access to vulnerable populations and survivors is key to responding to their needs, the agency of humanitarian NGOs is often viewed through the notion of 'humanitarian space' (Hubert and Brassard-Boudreau 2010; Sandvik 2016). After nearly three decades of use, the term remains poorly defined, but it generally refers to the ability of agencies, affected communities and international humanitarian law to respond to humanitarian needs in emergencies. Analytically however, humanitarian space is best approached as 'a complex political, military and

Kjersti Lohne

kjersti.lohne@jus.uio.no

1 University of Oslo, Postbox 6707, St. Olavs plass, Oslo, Norway 
legal arena', which 'highlights the highly political nature of the task humanitarian agencies seek to achieve and that humanitarian needs (and their relief) are a product of the dynamic and complex interplay of political, military and legal actors, interests, institutions and processes' (Collinson and Elhawary 2012: 1). However, despite the many overlaps and similarities between the two sectors, there is no equivalent analytic concept of a 'human rights space' in the human rights sector. ${ }^{1}$ Crucially, there is also a lack of critical consideration by scholars and practitioners of how the engagement of human rights NGOs with antagonistic actors, institutions, and states can have adverse consequences not only for the immediate human rights situation in question but also for the normative role of human rights generally.

To stimulate reflection on how human rights NGOs affect the 'human rights space' through access to, participation, and engagement with antagonistic actors, this article considers the role of NGOs at the US naval base in Guantánamo Bay, Cuba. Specifically, and on the basis of observation of pre-trial hearings for the case against Khalid Sheik Mohammed et al. - those allegedly responsible for the September 11 attacks, the article analyses NGOs as trial monitors of the US military commissions set up to deal with its prisoners - the so-called 'alien unprivileged enemy belligerents' detained at the base. ${ }^{2}$ In spite of continued efforts by human rights NGOs and incremental gains and improvements in the military commissions' institutional arrangements and practice, this article shows how NGOs have become so much a part of the everyday operation of justice at 'Gitmo' that they legitimate the military commissions' claim to be delivering fair and transparent justice.

The analysis is based on 2 weeks of field observation at Guantánamo Bay naval station and interviews with NGO representatives involved in trial monitoring on site and those in their headquarters in New York and Washington DC, and the military commissions' prosecution and defence teams, together with transcripts from press briefings I participated in. The material used for the following analysis mainly consists of observation of NGOs and their representatives, together with their reflections on the promises and pitfalls of delivering justice at 'Gitmo'.

The following section provides conceptual and contextual background on Guantánamo Bay naval station as an extra-judicial space of exception, the military commissions and the September 11 trial, and the role of NGOs in carving out a humanitarian and human rights space from which to approach 'Gitmo' - the military jargon for Guantánamo Bay (Rosenberg 2016). Following a brief methods section, section three provides an analysis of the trial monitoring of the military commissions, and the role of NGOs therein. It describes and explicates what trial monitoring at Gitmo is, who is involved, how it works, and why NGOs choose to be involved. Many of the NGOs monitoring the military commissions are not human rights organizations, but are nonetheless part of the 'human rights space' in which human rights NGOs operate. The analysis reveals how the NGOs' everyday participation as 'trial monitors' has come to legitimate the military commissions' claim that they administer fair and transparent

\footnotetext{
${ }^{1}$ Davies (2014) use the term 'human rights space' to refer to the space, or field, of human rights actors. Theirs is a more narrow approach than the one used here, which stands in parallel to humanitarian space emphasizing agency to promote and protect the agency of human rights organizations and the values and principles of human rights.

${ }^{2}$ Military Commissions Act of 2009, Public Law 111-84, available at: http://www.mc.mil/Portals/0/ MCA20Pub20Law200920.pdf
} 
justice. The final part reflects on what this may mean for both 'Gitmo' and for human rights monitoring going forward.

\section{Guantánamo Bay as Extra-judicial Space}

Since 11 September, 2001, the US naval base in Guantánamo Bay, Cuba, has been considered one of the foremost symbols of the 'global war on terror'. After the Bush Administration's intervention in Afghanistan, the naval base on the southern tip of the Cuban island was chosen as a place of detention for the growing numbers of captives apprehended by US troops in the theatre of war. Since the first prisoners stumbled out, masked and manacled, from an Air Force cargo plane onto Cuban soil on January 11, 2002, it has been estimated that almost 800 individuals from at least 40 different states have been transferred to and imprisoned in detention facilities at 'Gitmo'. ${ }^{3}$ When the prisoners first arrived, they had basically no rights whatsoever.

They were given neither lawyers nor hearings. Their identities were secret. The administration allowed no one to talk to the men to learn who they were, how there were captured, what they were doing when taken into custody, and how they were treated... The detainees were entirely cut off from the world at large held incommunicado on an isolated island base in the Caribbean (Cole 2016: 157).

Accordingly, Guantánamo Bay and its detention facilities have come to be characterized as a 'law-free zone' (ACLU 2008; Ratner et al. 2004) — a 'legal black hole' (Steyn 2004), 'beyond the law' (Honigsberg 2019; Amnesty 2002), and 'law-less' (HRW 2008). This was the diagnostic frame - that is, the 'identification of the source(s) of causality, blame, and/or culpable agents' (Benford and Snow 2000: 616) - of civil liberties and human rights activists in their naming and shaming of US policies in the war on terror. Pitting the Bush administration against the rule of law, they were, according to Cole (2016: 190) 'defending a central element of the American constitutional tradition: a government of laws, not of men'.

As such, the framing of Guantánamo Bay as a lawless space was successful in mobilizing domestic and international outrage and pressure on the Bush administration by bringing about, as we will see, incremental legal improvements. At the same time, the classification of Gitmo as 'lawless' is premised on a binary understanding of law (either present or absent) that carries with it three conceptual traps in properly understanding the relation between law, violence and political order as it manifested itself in Gitmo: First, law is a necessary condition of Gitmo's existence as an extra-judicial space; second, law is central to the everyday operation of Gitmo-indeed, there is an

\footnotetext{
3 Irrespective of relevance for both this article's analysis, and of the horrors of Gitmo, a study conducted by Seton Hall Law School based on US Department of Defense data found, among other things, that 55\% of the detainees were not determined to have committed hostilities against the US or its allies; that only $8 \%$ were characterized as Al Qaeda fighters; only $8 \%$ were captured by US troops but that $86 \%$ were arrested by the Northern Alliance or Pakistan and transferred to US custody at a time when the US offered significant financial bounties for suspected enemies; see Denbeaux et al. (2006).
} 
abundance of law regulating the 'law-free zone'; and third, positing Gitmo as law-free zone needing to be filled by law carries with it particular problems of legitimacy.

(i) As other scholars have long observed before me, the Bush administration's war on terror has been justified through legal arguments, instruments, and speech-acts (Johns 2013) - Gitmo no less. When the Bush administration realized they needed a place to detain and interrogate alleged enemies beyond the Afghan theatre of war and judicial oversight alike, the choice fell on the small strip of land on the Cuban island. The US claims to lease the territory of Guantánamo Bay from Cuba, as stipulated in a lease agreement from 1903 that gives - and ambiguously so'complete jurisdiction' of the territory to the US but 'ultimate sovereignty' to Cuba (Kaplan 2005). Following the Cuban revolution in 1959, President Fidel Castro has allegedly never cashed the check of \$2000 a year, calling the US presence on the island an illegal occupation (Gregory 2006; Reid-Henry 2007). This ambiguous legal space enabled the Bush administration to claim that its detainees at Gitmo had no constitutional rights before US courts, including the right to challenge their detention through a habeas corpus petition (a claim later overturned by the US Supreme Court in the 2004 ruling in Rasul v Bush). Moreover, the detainees were denied the status of 'prisoners of war', with corresponding legal protections under the Geneva Conventions. Rather, the Bush administration initially claimed its detainees were 'unlawful combatants' - neither civilians nor combatants - in the war on terror and as such, exempt from the Geneva Conventions outlining protections under international humanitarian law (see e.g. Greenberg 2009; Bravin 2013; Cole 2016).

In much of the academic literature, this legal construct of Guantánamo Bay as an extra-judicial space — what Judith Butler (2002) has referred to as 'Guantanamo Limbo' where both US constitutional as well as international law is suspendedhas been understood to epitomize the Italian philosopher Giorgio Agamben's concept of the 'state of exception' (2005). His accounts, which are bent on establishing modes of sovereign power, combine sovereign power to decide on the state of exception (building on Schmitt 2005 [1922]) with the concept of 'bare life' - the Roman figure of homo sacer delineating 'those who could not be sacrificed according to ritual (because they were outside divine law: their deaths were of no value to the gods) but who could be killed with impunity (because they were outside juridicial law: their lives were of no value to their contemporaries)' (Gregory 2006: 406). What makes Agamben's analysis so powerful is how his account has become intertwined with a system of sovereign power and state violence that still claim to apply the law. As such, he demonstrates how the normative aspects of law can be annihilated through the state of exception, and thus how the latter remains at the core of sovereign power.

However, as Gregory (2006: 407) observes, 'Agamben often refers to the state of exception as the space of exception, but its spatiality has received little sustained analysis'. For example, neither the colonial nor transnational conditions, power relations, laws nor implications of Agamben's 'state' receives his attention-his referent object remains the single state sovereign more than anything. However, as Massey (1994) argues, while space is the dimension of materiality, of jurisdiction and territory, it is also the land 'out there'- the 
dimension that confronts us with the simultaneous existence of 'the other'. As such, space is the dimension of multiplicity, always imbued with power and always therefore social and political. An enquiry into how the state of exception is 'emplaced' (Brigg and George 2020) at Guantánamo Bay is therefore an inquiry into its geography of power-into the relation between power, law, and spatiality. An objective of this article is thus to tease out how also transnational and non-state actors - human rights NGOs in particular-become part of this geography of power (Lohne 2019).

(ii) As an ethnographer, what struck me the most when physically encountering Guantánamo Bay - this infamous legal black hole - was how, contrary to both the international discourse and my expectations, Gitmo was filled to the brim with law, rules, regulations, and directives. Indeed, Gitmo is the space where I have most explicitly sensed law's presence (Ewick and Silbey 1998). It is a space of 'hyper-regulatory abundance' (Johns 2005), not only dictating the legal status of the prisoners and the prison guards, but of visitors - such as myself - and of life 'on base'. Upon arrival, my behavior was first diligently directed through a oneto-one 'operational security' welcome meeting at the base, before meticulously monitored by Joint Task Force Guantanamo that functioned in their capacities as my drivers, controllers, and entertainers ('did I want to go swimming on the beautiful beaches today'? 'Snorkeling'? 'To the pub'?). There is even a traffic court on base, ${ }^{4}$ and the iguanas crawling on the base are defined a protective species by US law (Ito 2008). In other words, rather than an absence of laws, there are rules of many sorts regulating life and bare life alike at Gitmo. Legal classification is part and parcel of its daily operation-it is a space "made governable' through law (Aradau 2007; Johns 2005).

(iii) The framing of Gitmo as an absence of law simultaneous frames it as a space to be filled and salvaged by law's presence. This assumption of law's redeeming powers is an underlying premise of the diagnostic frame of Gitmo as a lawless space. Yet it fails to see how both Guantánamo Bay is both brought into being and operates under a logic of law. Questions must thus be asked of whether such an approach risks legitimating its existence through small, incremental improvements - or additions - of law. Indeed, it is precisely such a dynamic that characterizes the military commissions set up on Guantánamo Bay to prosecute the 'alien unprivileged enemy belligerents' for, among other things, violations of the 'law of war', 5 and, as I will turn to shortly, human rights monitoring on the military base.

The legality and legitimacy of the US military commissions remain highly contested. Indeed, they have been subject to legal-political 'ping-pong' in the US since their inception. First established in 2001 by executive military order by President Bush, their authority was soon disputed by the Supreme Court in Hamdan v. Rumsfeld, which found that the institution 'lacked power to proceed because its structure and procedures violate both the Uniform Code of Military Justice and the Geneva Conventions' (Duffy

\footnotetext{
${ }^{4}$ Navy pilot administers justice in Guantánamo's other court | Miami Herald

${ }^{5}$ Military Commissions Act of 2009, $\$ 948$ b, available at: http://www.mc.mil/Portals/0/ MCA20Pub20Law200920.pdf
} 
2015: 687). Since it lacked the power to establish such commissions, the Bush Administration sought approval from Congress, and authorization was granted by the 2006 Military Commissions Act, under which several detainees were tried and convicted. Two days after taking office, however, President Obama put a stop to the military commissions by executive order, and declared his intention to work towards bringing Guantánamo and its detainees within the normal legal process, which in this case would mean criminal prosecution in ordinary civil courts. However, this met with immense opposition from Congress, which blocked the entry of Guantánamo detainees onto US soil, and thus led the Obama administration to consolidate the use of military commissions, albeit in a slightly improved form (Duffy 2015). In other words, the current form of the military commissions are a product of a compromise between no judicial process at all, and the impossibility of a mainland court process (where also the circumstances of the prisoners' capture and treatment in US custody - that is, kidnapping and torture - would complicate cases for the prosecution).

\section{The September 11 Trial}

Today, only Abd al-Rahim al-Nashiri, Abd al Hadi al Iraqi and five men accused of planning the September 11 attack face formal charges before the military commissions. Khalid Shaikh Mohammed, Walid bin Attash, Ramzi bin al-Shibh, Ammar al-Baluchi and Mustafa al Hawsawi are accused of having directed or trained the September 11 hijackers or having helped them by providing money or assistance with travel. The formal charges against them include conspiracy, murder in violation of the law of war and terrorism - charges which carry the death penalty. After their capture in 2002 and 2003, they were held in various CIA 'black sites' - a global network of secret prisons - before being transferred to Guantánamo in $2006 .{ }^{6}$

Nearly two decades after the September 11 attacks, the case has not got beyond the pre-trial hearing phase and it remains unclear when the actual trial will begin. Indeed, the case is in stalemate over 'discovery', that is to say, the disclosure of evidence against the five men. Because the prosecution constantly invokes national security, the defendants' ability to refute accusations in the military commissions is extremely restricted, due to non-disclosure of evidence. The legal process is beset by a fundamental contradiction: that between, on the one hand, government efforts to prevent disclosure of its own crimes, committed in the course of the war on terror, and - on the other - the efforts of the defence lawyers to safeguard their clients' fundamental right to a fair trial.

For example, during hearings in 2016, it became clear that the judge had permitted the destruction of evidence believed to be of possible use as mitigating evidence for the defendants. What the evidence consisted of is classified, but is assumed to be related to one of the CIA black sites. Destruction of evidence is only one of many violations of the right of the accused to a fair trial: computers and confidential communications between lawyers and clients have been seized or monitored; smoke detectors in meeting rooms have hidden surveillance gear, and many defence lawyers' homes have been broken into. Some years ago, the FBI also infiltrated a defence team by recruiting

\footnotetext{
${ }^{6}$ See https://www.nytimes.com/2020/02/03/us/politics/september-11-trial-guantanamo-bay.html?auth=loginemail\&login=email (last accessed 1 August 2020).
} 
informers among them. In 2015, it came to light that one of the defendants' translators had previously worked as a CIA translator-the defendants recognized him because they had encountered him at one of the black sites (Lohne 2017a).

Whether the military commissions at Guantánamo-including its rulings and potential convictions - will stand the test of time remains to be seen: the US Supreme Court has not (yet) dealt with the jurisdiction of the current modicum of military commissions. Such legal uncertainties add insult to injury for those awaiting justice in the form of final convictions and executions, such as some family members of September 11 victims. It is quite possible that they too may be waiting in vain because the proceedings are stuck in a legal quagmire which includes everything from the judge's impartiality to poisonous gases at 'Camp Justice', which houses the temporary court rooms and the court observers. As in any justice process, there are opposing interests, but the victims' - and the public's — need for justice after the September 11 attacks has come up against a judicial process that cannot be conducted as a fair trial. A small number of people are allowed to fly to attend the legal drama taking place at 'Camp Justice'. Half of them are there to observe a justice process relating to September 11 - the other half to observe a process regarding the use of torture. It is an ironic twist of fate that the justice process post September 11 has become a forum where judgment will be passed not only on terrorism, but also on the global war on terror (Lohne 2017a; Haire 2020; McCall-Smith 2020).

\section{Civil Society and Human Rights Activism}

As Cole (2016: 153) observes, '[t]hose who wanted to protect civil liberties and human rights in the wake of 9/11 faced considerable headwinds'. Nevertheless, both US-based civil liberties organizations and international human rights NGOs have been fierce critics of US policies in the war on terror using a varieties of tactics. For example, since the US first sent prisoners to Guantánamo in January 2002, human rights NGOs have mobilized the law against the unlawful internment and treatment of detainees there. Through the 'John Adams project', the American Civil Liberties Union provided legal representation for detainees, and together with other US civil liberties bodies, such as the Center for Constitutional Rights, these organizations were indispensable in litigating habeas corpus cases for the detainees, ${ }^{7}$ and advocating and lobbying for legal improvements in revised versions of the Military Commissions Act (see Denbeaux and Hafetz 2009; Cole 2016).

Human rights NGOs such as the US-based Human Rights First, together with international organizations such as Amnesty International and Human Rights Watch and UK-based Reprieve and REDRESS, have also mobilized international attention in various fora, including the United Nations' universal periodic review, and the UN Special rapporteur on torture and working group on arbitrary detention. Increasingly, they also became involved in litigation on behalf of Guantánamo detainees in domestic and international courts and judicial fora. These include the Inter-American Commission on Human Rights (IACHR), and the European Court of Human Rights (ECHR), where efforts are made to hold European states accountable for their contribution to and

\footnotetext{
${ }^{7}$ Habeas corpus refers to a legal right enabling a person to report unlawful detention and request a court to determine whether their detention is lawful.
} 
facilitation of the CIA interrogation, rendition and detention programme by the extraordinary rendition of abductees on European soil (Duffy 2015).

However, the ability of human rights NGOs to use 'information politics' (Keck and Sikkink 1998) - that is, to generate accurate information for use in domestic and international advocacy - has been far from an easy task. Guantánamo Bay, its prisons, prisoners and military tribunals are shrouded in secrecy, and the presence of NGOs were not only initially refused but remain strictly limited on what is essentially a high security military base.

Among external actors, to date, only the ICRC has been granted access to the prisoners. ${ }^{8}$ On principle, this humanitarian organization does not disclose information to the public, which is why they were initially granted access to the facilities (Greenberg 2009). As the patriarch of modern humanitarianism, the ICRC's imperative is to give assistance according to need, and according to principles of humanity, impartiality, independence and neutrality. ${ }^{9}$ Thus, its access to the prisons is contingent on maintaining confidentiality. According to the organization,

Confidentiality is an important working tool for the ICRC in order to preserve the exclusively humanitarian nature of its work. The ICRC is concerned that any information it divulges about its findings could easily be exploited for political gain. Moreover, the policy of confidentiality ensures that the ICRC obtains and, importantly, maintains, access to tens of thousands of detainees around the world. $^{10}$

That being so, leaked reports from the ICRC became an important source of information about conditions in the facilities in the early days of Guantánamo Bay. ${ }^{11}$ At the same time, their access - and subsequent information — about the prisoners also became beneficial to the US authorities. As Greenberg (2009: 102-103) notes:

Far from 'interfering' with a highly sensitive American mission, as War Council had worried, the humanitarian group was making the detention operation work more smoothly. The JTF had finally broken through the detainees' wall of silence. They were finally getting reliable information about the individuals they had in custody. And they ferreted out this information not by cruel and degrading treatment but, on the contrary, by following Common Article 3 of the Geneva Conventions.

The use and abuse of ICRC's presence at Guantánamo Bay demonstrates some of the dilemmas embedded in the conflicted nature of their presence, including the compromises they make to safeguard their access to those in need. Indeed, the history of the

\footnotetext{
${ }^{8}$ The UN Special Rapporteur on Torture has conducted investigations but not on-site as the terms of reference for the visit was not agreed upon as he was denied private access to the detainees (Nowak 2009; Mukherjee 2011).

9 There are of course great differences between humanitarian organizations too. For an introduction, see Barnett (2005).

${ }^{10} \mathrm{https} / / / \mathrm{www}$. icrc.org/en/doc/resources/documents/update/5qrc5v.htm (accessed 2 August 2020).

${ }^{11} \mathrm{See}$ https://www.swissinfo.ch/eng/icrc-condemns-leak-of-us-torture-report/7327042 (last accessed 4 August 2020).
} 
organization is laden by moral comprises, epitomized by their decision not to speak out publicly on what was going on in the Nazi concentration camps during World War II (Moorehead 1998). The relationship between humanitarian and political spaces is a complex one, and one which is much discussed both in academic commentary as well as by humanitarian professionals themselves (see Dieckhoff 2020). For example, disheartened and frustrated by the ICRC's unwillingness to 'speak out' against the human rights violations it witnessed during the Biafran Civil War, precisely in order to secure access, a fragment of the ICRC broke out to form Medicins Sans Frontiers in 1971 (Dixon 2019). Thus, as the humanitarian movement has grown increasingly diverse and complex, typologies of humanitarian organizations' ideal types have emerged, often pitting 'Dunantists' (after ICRC's founder Henry Dunant) against 'solidarists' campaigning against a lack of intervention in the name of humanitarian solidarity. As Rieff (2003) argues, this has made some humanitarian organizations not only ardent supporters of military intervention but also misused and co-opted by military state power, as demonstrated by the US Secretary of State Colin Power describing NGOs as a 'force multiplier' and 'part of the combat team' as well as President Bush' statement upon the 2001 invasion of Afghanistan that:

[T] he oppressed people of Afghanistan will know the generosity of America and our allies. As we strike military targets, we'll also drop food, medicine and supplies to the starving and suffering men and women and children of Afghanistan (quoted in Dixon 2019: 827; see also Slim 2004).

Thus, alongside debates on 'military humanitarianism', the humanitarian sector has wrangled the question of how to operate and safeguard their 'humanitarian space'including not only a physical space from which relief can be provided but also access, security, and independence as fundamental principles of humanitarian space as a 'operating environment' for humanitarian action (see Hubert and Brassard-Boudreau 2010).

Less attention however, has been paid to the 'operating environment' of human rights organizations - despite the fact that there exists a plethora of critical human rights literature, including on the convergence of human rights with state power and military intervention (e.g. Douzinas 2007). Human rights NGOs have a tradition of 'speaking truth to power' (e.g. Keck and Sikkink 1998). Indeed, human rights advocacy has been driven by the assumption that knowledge about suffering leads to action, which lies behind the well-known human rights tactic of holding states politically accountable through 'naming and shaming' their human rights records (for an empirical evaluation, see Hafner-Burton 2008). In contrast to humanitarianism, which operates in an on-going state of emergency, ${ }^{12}$ human rights NGOs have a much longer timeframe. They seek to address individual and systemic injustices suffered in the past, to establish accountability for violations of human rights and international law. Yet, little is known about the practical realities and political sacrifices made 'on the ground' of human rights work, and especially not within a shared space with the very same state power that it seeks to bring to justice. To this end, the following analysis delves into the

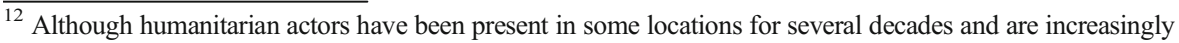
present in protracted conflicts, states of emergency animate their intervention (Fassin and Pandolfi 2010).
} 
'human rights space' at Guantánamo Bay through an ethnographic account of human rights monitoring of the military commissions.

The importance of such a probe is underlined by the fact that despite the strenuous efforts of human rights NGOs to dismantle Gitmo, there has been very little attention to the role of NGOs at Guantánamo or to the military commissions specifically - and no systematic research. Although the commissions are a domestic institution, they are essentially a war crimes tribunal, lent legitimacy by international humanitarian law and international criminal law (for a critique, see Hafetz 2013). As accounted for above, the commissions deny the applicability of human rights law as the US argues that human rights law only applies territorially and that Guantánamo is not US territory. Yet, in their current modicum, the commissions nevertheless claim to pursue and deliver 'fair, transparent, justice' in accordance with US law and the laws of war. ${ }^{13}$ As part of this, they have since 2006 invited representatives from civil society such as 'NGO observers' to attend the commission hearings at Guantánamo. In what follows, I offer an analysis of how this affects the legitimacy of the military commissions. First, however, some brief comments on methods are in order.

\section{Doing Research on and at Gitmo}

During the summer of 2016, I spent 2 weeks as a trial monitor of the pre-trial hearings in the case against Khalid Sheik Mohammed et al. I was granted access as a media representative (for the Norwegian newspaper Aftenposten), and was - apart from the detainees - the only non-US citizen on the base at the time. In order to physically access the US naval base in Guantánamo Bay, Cuba, complete dependence on the US military for access, transport, food, lodging and security, had to be accepted. The vetting processes, the need to sign dozens of pages of base ground rules and the Operational Security (OPSEC) lessons upon entry, all combine to confront the ethnographer at 'Gitmo' with major challenges regarding what she can and cannot do, see, hear, and, not the least, write about. Gusterson (1997), in his ethnography of a nuclear weapons laboratory in California, points to the obstacles to 'studying up', particularly in terms of gaining access to (military) elites. '[P] articipant observation is a research technique that does not travel well up the social structure' (1997: 115). He suggests that ethnographers should embrace what he calls 'polymorphous engagement', which 'means interacting with informants across a number of dispersed sites, not just local communities, and sometimes in virtual form; and it means collecting data eclectically from a disparate array of sources in many different ways' (1997: 116). Staying in 'Gitmo' under intense surveillance was enlightening in terms of understanding its everyday practices and social hierarchies, but - as Gusterson suggests - an eclectic mix of other research strategies also needed to be adopted.

During these 2 weeks, I interacted with, observed, and interviewed major stakeholders in the military commissions, including prosecution lawyers, the defence team, members of the joint task force, family members of September 11 victims, other journalists, and NGO representatives. After my visit, I interviewed NGO representatives at their headquarters in New York and Washington DC about their presence,

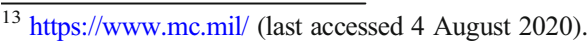


advocacy, litigation and other types of work at Gitmo. I was also granted access to observe a Periodic Review Board at the Pentagon, which is an administrative quasijudicial process determining whether there are grounds for the continued detention of prisoners at Gitmo. In the following months, I also conducted interviews with human rights NGO workers in London and The Hague.

The data gathered consists of 15 interviews, 11 of which were conducted with NGO representatives, and a field work diary containing observations and interaction notes on the defence teams, NGOs, and media throughout the 14 days at Gitmo. Material came from hanging outside the courtroom during courtroom breaks, inside 'tent city', at barbecues organized by people working for the defence, at the military canteens, at dinner and drinks with defence lawyers at 'home' and in bars, and shorter and longer conversations one-on-one and in groups with NGOs, media, defence counsels, Joint Task Force Guantanamo (the soldiers), prosecution and families of September 11 victims. I also participated in six press briefings and conferences with the above stakeholders. In addition, sources from investigative journalism, such as the New York Times The Guantanamo Docket and reporting by Carol Rosenberg ${ }^{14}$ (formerly on the Miami Herald, now with The New York Times), were used for fact checking and to confirm background. Another source is the plethora of blogposts on trial observations at Gitmo, most of which are written by representatives of the various NGOs that are granted access to hearings. The triangulation of interviews, observation, and (online) representations provide a holistic analysis of NGO trial monitoring at the commissions, in contrast to methodological approaches that base their analysis upon, for instance, online briefs and representations (Carpenter and Jose 2012).

That said, the observations at Gitmo only cover a 2-week period in 2016. Furthermore, I was supervised/monitored by military minders almost the entire time, and my access while at Gitmo was also very limited. Questions can thus be asked about whether what comprises the key findings has been made on the basis of both data and analysis, and how such potential adjustments impact not only the ethics of the study but also its validity. In doing so, it is important to keep in mind that my aim is not to depict a 'full account' of Gitmo, nor to reveal any secrets. For starters, this would be an impossibility, given that I did not have access to confidential information, that is, 'operational security'. Rather, and paraphrasing Walters and Luscombe (2019: 73), my task was not to disclose a singular, hidden truth as much as to document and interpret the way in which actors reanimate the space of exception in the present. While it was a physically and mentally uncomfortable experience, at the same time, it was perfect for carrying out ethnographic observation. Being a trial observer at Gitmo means operating in a bounded social space, where everybody has a well-defined role as a soldier, prosecution lawyer, judge, defence lawyer, NGO or media representative, victim's family member or civilian contractor providing food or services. Because Gitmo is so small, it provides a microcosm of how order and the space of exception is negotiated in everyday social practices. I also had a gate-keeper whose significance for my stay there, as well as for the lasting legacy of Guantanamo, cannot be underestimated. Carol Rosenberg has been reporting on and from Gitmo since the first prisoners set foot there, and she provided me with key insights into the workings of the notorious space of exception and much more. The volatility of the field not only affects how empirical

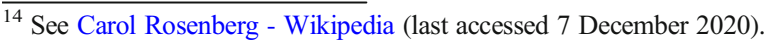


investigation is conducted but also the research project's validity. This is a field in flux, subject to events and political decisions that have the potential to significantly change the conditions - and indeed the existence - of the military commissions and of Gitmo altogether. To a certain extent then, this analysis is contextual, informed by specificities of space and time. However, this article also aims to tease out elements and qualities in human rights monitoring that are more permanent.

\section{Trial Monitoring at Guantánamo Bay}

Court or trial monitoring is a widespread practice carried out by NGOs to ensure the right to a fair trial, including open and transparent justice processes. According to 'Manual on Human Rights Monitoring' commissioned by the UN High Commissioner for Human Rights, the ultimate objective of trial observation is 'To evaluate the fairness of the trial in the light of its conformity with the applicable domestic law and international human rights standards and its protection of the interests of the accused. ${ }^{15}$ In addition, there are other objectives, such as signalling interest and concern in the trial to the punishing authority, to contribute, by being present, to an atmosphere favouring 'fair trial', to provide moral support to the accused, and to obtain information about the legal proceedings and the context of the trial more generally.

According to the Manual, there are several issues to consider when 'Assessing whether or not to observe a trial'. Among these are the nature of the charge, the representative nature of the trial, the significance of the trial itself, the existence of structural irregularities, the existence or prospects of irregularities in governmental conduct, and the possible negative effects of trial observation. The latter relate to the safety of the accused and his or her family, and such questions as "What is the likelihood that the government of the country where the trial is taking place will use the presence of the trial observer as an excuse to pursue harsher measures than normal for the offence at issue?'16

However, the Manual gives little guidance on how to approach these questions, except for a general comment that the decision on whether to observe should be based on whether such 'a mission will be of value in protecting the rights of the accused or otherwise advancing the cause of human rights in the country where the trial is taking place'. ${ }^{17}$ To what extent does trial observation by NGOs at Gitmo protect the rights of the accused and advance the cause of human rights in the US? The intention is not to identify a direct effect of NGOs' trial observation at Gitmo in the form of human rights impact in the US. Instead, the importance of analysis of NGOs' interaction with the military commissions lies in observing the dynamics of their involvement, and in the complexities of the processes shaping the military commissions.

At Guantánamo and in the military commissions, observation of proceedings by NGO representatives has become an integral part of hearings. When hearings for the

\footnotetext{
${ }^{15}$ Manual on Human Rights Monitoring, Chapter on Trial Monitoring. p. 2. https://www.jus.uio.no/smr/ english/about/programmes/nordem/publications/manual/

${ }^{16}$ Manual on Human Rights Monitoring, Chapter on Trial Monitoring. p. 1-2. https://www.jus.uio.no/smr/ english/about/programmes/nordem/publications/manual/

${ }^{17}$ Manual on Human Rights Monitoring, Chapter on Trial Monitoring. p. 1. https://www.jus.uio.no/smr/ english/about/programmes/nordem/publications/manual/
} 
case against the alleged September 11 conspirators are scheduled, a press release is posted on the Department of Defense's (DOD) website inviting NGO observers to be present. On the airplane leaving a military base outside Washington for Guantánamo Bay Naval Base, 14 seats at the very back of the aircraft are reserved for NGO observers; there are a few more for journalists. In front of them, in the usual hierarchical order found in planes, sit the defence teams, military commission support staff, and the prosecution team; the judge and victims' family members are up front, in 'business class', as it were. In a similar symbolic fashion, victims' family members are accommodated in small townhouses on the base, while NGOs and journalists sleep, shower and do other such things in military tents on 'Camp Justice', which houses what Carol Rosenberg refers to as 'camp city' and the 'expeditionary legal complex' where commission hearings take place. In contrast to journalists, who pay for their flights, NGO observers fly free, leading certain commentators to refer to them as 'guests' of the military commissions.

\section{Who Observes Justice at Gitmo?}

There are far fewer human rights NGOs at Gitmo than one might expect, given the number found in other courts where war crimes are prosecuted. At the International Criminal Court for example, civil society participation mainly comes down to human rights organizations and their involvement in the day-to-day advocacy, lobbying and implementation of international justice (Lohne 2018). At Gitmo, the civil society organizations involved in court observation and monitoring are a diverse mix of human rights bodies, national bar associations, universities, law schools, human rights clinics, think thanks and numerous issue-specific groups. Although housing a 'global war prison' (Gregory 2010), this serves as a reminder of the national space which indeed Guantánamo Bay is - civil society participation is to a large extent synonymous with the US public (in contrast to service personnel on the base who are mainly from Jamaica and the Philippines and as such, serve as a potent reminder of the colonial space that Guantánamo Bay also is (see Reid-Henry 2007)). According to one representative: 'NGOs stand for the American public. Because there is a diverse mix of NGOs, you have a diverse analysis from different perspectives. This adds to the overall evaluation'. This reflects a view that does not regard human rights NGO monitors as morally superior - by virtue of their cosmopolitan and universal values - to those from other NGOs, but rather places them on an equal footing, as part of American civil society.

Five organizations have 'permanent seats' on the plane, which means that they are prioritized if all 14 seats are booked. These five are all big multi-issue organizations: the American Bar Association, Amnesty International, Human Rights First, Human Rights Watch, and the American Civil Liberties Union. It is generally assumed that the five have a particular role vis-à-vis the commissions, since they have had significant involvement from early on. Other bodies have also been closely involved at times, but, perhaps because they are less firmly established, their participation has ebbed and flowed, since they are dependent on funding and individual initiative. Other approved organizations that apply to observe commission hearings get a seat on the plane if there are 'NGO seats' available, and take turns if there are more than 14 NGO representatives interested in observing hearings. In my second week of observations, however, there were only nine NGO representatives present. 
Of the 23 approved NGOs at the time of research, seven were universities and human rights clinics. There were four lawyers' and bar associations accredited, and these were mainly represented by senior professionals with criminal law expertise. As will be discussed further below, the three human rights NGOs sent interns to observe the proceedings. The remaining bodies included various civil liberties organizations, think tanks, specialized NGOs and a victims' organization. The NGOs approved to observe the military commission hearings were: the National Institute for Military Justice, the National Association of Criminal Defense Lawyers, the Heritage Foundation, the Brennan Center, the New York City Bar Association, Seton Hall University School of Law, Judicial Watch, the University of Toledo, Duke University, the National District Attorney's Association, the University of New Mexico School of Law, the Pacific Council of International Polity, the Henry Jackson Society, the Open Society Foundation, Indiana School of Law, the Geneva Academy, Georgetown University Law Center, and Peaceful Tomorrows. ${ }^{18}$

Because such a large part of the NGO group is composed of universities and law clinics, their representatives are generally law students. During my observation, I met both first- and second-year law students; their presence is seen as a bit 'problematic' by other NGO representatives and defence lawyers. Some question the students' ability to do any 'real' court observation due to their lack of legal knowledge; it merely enables them to put on their CVs that 'they've been to Gitmo'. Some welcome their participation as long as there are not too many of them at the same time - apparently, it has an effect on the dynamics of the NGO group - too much laughing, too much drinking, too much snorkelling, perhaps? Others see them as kids just wanting to 'go to Gitmo, get their coffee mug, and go home'.

While senior representatives from human rights and civil society organizations have been to Gitmo in the past, the shift from senior to junior personnel can be seen as part of a general 'Gitmo fatigue' and of the lack of progress and newsworthiness of the military commission hearings. As one NGO representative put it,

We were just down there. I think it's really important, and especially in the beginning, it felt like 'Oh, this is something that's going to be - like, where we could perhaps make some headway'. But, as you know, the trial, it's so stagnant. We're still in pre-trial phase. Most of the time you'd go down there, it would get cancelled, and because you're on these chartered flights, you can't get out.

Another element is the sense of urgency. Gitmo and the military commissions are simply not as urgent now as they were back in the day. And apart from a general 'Gitmo fatigue', this has to do with the fact that in the early days of the military commissions, human rights NGOs such as the ACLU were concerned that they should represent a new and permanent system of justice. Today, the commissions are not used for any new cases, and while the September 11 case is often referred to as the 'trial of the century', the question must be asked whether the situation feels less pressing today

\footnotetext{
18 The list of accredited organizations is constantly updated, which means I have not seen details of the historical development of NGO accreditation. The list is not made available to the public, but I was able to get it from the NGO public affairs officer by e-mail. Several NGO representatives I spoke with had not seen the list; contact information about one's fellow NGO observers was not provided by the military commissions, and my request for this information was ignored.
} 
than it used to. In what follows, I suggest that the fact that there is a predominance of students and interns rather than professionals must also be seen in relation to the materialities of trial monitoring at Gitmo, and the power relations embedded in these spatial relations.

\section{Everyday Observations at Gitmo}

During military commission hearings, NGO observers, media, and victims' family members can observe the hearings from the 'public' gallery at Camp Justice-when the hearings are in open session, that is. During my 14 days at Gitmo, I-along with the NGOs - were able to observe only 5 days of hearings; on the other days, the pre-trial hearings for the September 11 case were either in closed session (dealing with classified information), or in recess. Yet even when the hearings are observed from the public gallery, audio is delayed by 30 seconds which enables the military commissions, or the CIA, to censure any information that is classified, or they might want to have classified. In the public gallery, a curtain separates the victims' family members from the NGOs and the media. While this is motivated by respect for the privacy of victims' family members in a situation that might be upsetting for them, the curtain also physically separates civil society into two distinct groups, demonstrating how material expressions arrange space and reflect social and political relations. There is limited interaction between the two: they enter and exit separately, they live separately and, generally, it seems, they interact with different parts of the military commissions: the victim's family members are taken care of by the prosecution, while the defence teams handle NGOs and the media. For example, on the day of arrival, one of the defence teams invited the NGOs to a barbecue to give them a briefing on issues that would be dealt with in hearings in the forthcoming week. They did the same with the new group of NGOs that arrived the following week. The victim's family members have a staff member from the military commission at their disposal. During short breaks and after hearings, the defence lawyers make themselves available - if they have time - to answer questions, but I was told they are seldom approached by victims' family members. There are rumours that the prosecution and the military commission staff advise victims' family members not to interact with defence lawyers, NGOs or the media. When the hearing was delayed one day, the chief prosecutor came in person to the public gallery to explain to victims' family members why this had happened - a form of interaction that it is hard to imagine happening in either domestic or international criminal proceedings. While this division is not absolute-occasionally, there are people who move between the two sides - it seems this is generally the social set-up at Gitmo. In the evening, at the Irish pub O'Leary's, victims' family members sat at one table, NGOs at another, the media at a third. Later, NGOs and journalists wanting a nightcap might join forces at the tables outside the tents in Camp City. Meanwhile, victims' family members were in town houses in 'downtown Gitmo'.

The NGOs have a 'NGO room' at their disposal in a bunker, if they want to sit in a cool place and work. However, work at Gitmo is difficult. One issue is that, as one is dependent on the chartered military aircraft to get in and out of Gitmo, it is difficult to do other types of work while there. During my observation, one of the criminal defence organization's representatives became very frustrated because the return flight was delayed by more than $24 \mathrm{~h}$, which meant she was missing meetings she should have 
been having with clients. Moreover, satellite internet access costs at least 150 dollars per week, and working conditions are poor, to say the least. Gitmo is far from being a comfortable place to stay: you sleep in military tents with noisy and freezing cold air conditioning (the alternative is worse), shower in fungus-infected tents, heavily marked with the warning DO NOT DRINK THE WATER (due to environmental hazards); there is the heat, the dependency on military escorts to go anywhere or do anything, and the general oppressiveness of simply 'being' at Guantánamo. It is an arduous, even hostile space to 'be' in- even for those at liberty to leave on the next plane out. The difficulty of maintaining a busy work schedule also seems likely to be a factor in NGOs' decisions on who to send to Gitmo, and why the choice often seems to fall on interns. As explained by an NGO representative,

It just takes a lot of resources for organizations to send individuals, and it's not like your work back home has ended....it's not as if you could even get anything done while you were down there. It was really horrible... They don't make it comfortable, they don't make it easy, you know.

Being sent there might also be of benefit to interns, as it is a way to get 'field experience'. They send reports back to headquarters. During their time off, which there may be a lot of, depending on whether court sessions are open or not, the NGOs go to the beach to swim and snorkel, go on boat trips or tours to the base's borders with 'real' Cuba, or just hang out in the NGO room or at the outdoor café serving Starbucks coffee. One NGO representative recalls,

I don't know if this is still happening or not, but there was a time when we were going down there that was almost like a PR effort to make it feel as if we were going down for a vacation. They would offer to take us on fishing trips, or like have a bonfire on the beach, and a lot of us were like 'uh, no - that's not what we came down to do'... I think it's because we were complaining a lot.

These elements of trial monitoring at Gitmo raise the issues of whether 'being' there matters more than what is 'done' there, and of the importance of having trial monitors that are capable of making this distinction.

\section{Why Go to Gitmo?}

The diversity of the NGO group is matched by the diversity of their motivations for conducting (pre)trial observations at Gitmo - in the case both of individuals and of the organizations they are representing. Some of those representing bar associations (the New York Bar Association, the American Bar Association) said they were simply curious and interested to learn more about the procedures of the military commissions. On the last day, one of them frowned, saying 'this has nothing to do with justice'. Such people write a short report or a blog on their experiences and their reflections on what they have seen.

This is also what the human rights NGOs do. Interns or officers write reports on what has been going on in the case, and end by calling for the commissions to be closed and for detainees and the charges against them to be dealt with by civilian criminal courts. 
Yet, from the perspective of organizations' headquarters, going to Gitmo serves multiple purposes. Although one of the major human rights NGOs said, 'there was some consideration at some point of, you know, let's not go at all', the gains from 'being there' seem to trump other considerations. First, it appears that it is considered important just to show that they are still watching, keeping 'Gitmo' in the loop. Also, according to one NGO,

It gives us the ability to, you know, talk to policy makers in DC - at the White House, the Defense Department, on Capitol Hill - from the perspective of having on the ground expertise, and to be able to say, you know, 'this is actually happening'.

Another NGO representative had a similar view,

There are added layers of nuance to actually being in the courtroom and seeing the detainee, and observing the proceedings and the body language, and talking with the defense counsel when you're there, and with the prosecution, to take in all sides of the argument and formulate an opinion. It is certainly a lot easier than reading about it on Twitter or reading the documents or even watching it from Fort Meade via a video feed... That being said, I don't want to overstate the case. It is certainly costly and time-consuming to send someone there. For that reason, it's been a number of years since I've gone, and you know, we have a number of legal interns and staff members who have the time, the interest and the ability to go, but if we were a one-staff organization, it might not make sense to send someone there every single week...

As regards law students, the situation is less clear. For some, it seems just to have been a fun idea to sign up to, when given the opportunity by their school or an affiliated organization. Someone from one of the accredited organizations even sent her children: in my first week of observation, her daughter, in my second week, her son.

\section{Legitimating Justice at Gitmo}

This article has not dealt with the significance of NGO work on Guantanamo beyond trial observation. After all, trial monitoring remains a minor part of many of the organizations' activities. The big five organizations, for instance, are all heavily involved in NGO advocacy and lobbying, particularly in Washington DC, where they work to 'change the system' at the political level by lobbying Congress and other politicians and policy-makers. As explained in the introduction, many of them also employ legal strategies - both at the national level through litigation and by providing legal assistance, and at the international level through advocacy and cooperation with international fora such as the UN working groups on human rights, torture, and arbitrary detention, and by providing assistance in cases before the ECHR. In other words, these human rights NGOs do important work on closing Guantánamo and the military commissions, which goes beyond trial observation. It must therefore be asked if trial observation on site is worthwhile. 
In answer to my question about how the military commissions responded to human rights NGOs' criticisms, the then Chief Prosecutor of the military commissions, General Martins, said:

Civil society, non-governmental organizations, private advocacy groups have roles in public trials - an important role.

The presence of NGOs - as part of civil society, along with the media - is considered an important element in the administration of justice because it contributes to making the military commissions transparent. ${ }^{19}$ This accords with the argument put forward at the international level, where the participation of NGOs is seen to 'fill in the gaps' of the democratic deficit problem of international governance (Glasius 2002; Scholte 2018). Their authority is normatively claimed, not for the sake of political representation and partisan interests, but morally - they claim to represent the cosmopolitan, transcendent and universal, as materialized in human rights (Lohne 2017b). However, at Gitmo, this claim to detachment from politics is flatly dismissed by the military commissions. According to General Martins,

They [NGOs] are also accountable to whomever they represent - to private interests, non-governmental interests. Prosecutors, public prosecutors have to be accountable to the people through their lawfully elected government and lawfully appointed positions. So we are representing everyone.

In other words, human rights NGOs are considered of some importance to the process because they are part of civil society, representing one of many views of it. They are not, however, regarded as having moral authority. Indeed, quite the opposite appears to be the case: human rights NGOs represent particular interests, and are therefore biased, while the military commissions and the office of the Chief Prosecutor represent the US 'people'. In this view, the military commissions, not human rights NGOs, are beyond politics.

The question therefore arises whether human rights NGOs' continued presence and participation in the everyday process of administering 'justice' at Gitmo mean that they help legitimize the system. As pointed out by Kelly (2019), human rights monitoring, in general, 'clearly has its limits as a model of change'. One of the issues identified is the fact that there are situations where, although the world knows about torture or other types of human rights violations, nothing is done about it. In such circumstances, as is the case at Gitmo, human rights NGOs' everyday participation may be seen to 'normalize' the state and space of exception alike, and thus, in effect, inadvertently narrow a 'human rights space' they originally set out to expand.

\section{Conclusion}

On the basis of fieldwork observation and interviews with key stakeholders in the September 11 case before the military commissions at the US naval base on

\footnotetext{
$\overline{{ }^{19} \text { Press briefing on file with author. }}$
} 
Guantánamo Bay, this article suggests that more attention should be given to the effects of human rights reporting. It argues that human rights NGOs have become part of the everyday at Guantánamo Bay, and that Guantánamo Bay itself has become permanent, normalized and unaffected by the urgency that usually characterizes contexts of human rights reporting. Questions should thus be asked about whether human rights NGOs, through their continued and 'normalized' presence, have become part of a process of structural legitimation of the military commissions at Guantánamo Bay. This raises two elements of concern going forward:

First, where does this leave the fight to end Guantánamo today? While the political consequences of the incoming change in the White House is certainly more uplifting than the Trump administration's (hollow, thankfully) promise of 'loading it [Gitmo] up with bad dudes', this article has demonstrated a temporal elongation of the space of exception that is characterized more by the subtle and social than the spectacular and political. Through observing justice at Gitmo and in a trial considered no less than epochal of a defining moment in US history, the space of exception is constituted not only by the sovereign power to annihilate the normative aspects of law, but also by producing an infrastructure - material, social, legal — that legitimizes its existence.

Second, where does this leave the fight for human rights? As human rights NGOs have become part of this infrastructure, there may be grounds for asking what types of human rights engagement help increase, or, albeit unintentionally, contribute to narrow the operating environment of human rights NGOs. Such a shrinking of 'human rights space' is particularly alarming in this time of considerable pushback against global human rights norms (Alston 2017; Dudai 2017).

Acknowledgements I would like to thank Katja Franko and the early career research network at the Department of Criminology and Sociology of Law at the University of Oslo for engaging with an earlier draft of this article. Faults are entirely my own.

Funding Open access funding provided by University of Oslo (incl Oslo University Hospital). The research for this article was funded by PluriCourts - Centre for the Study of the Legitimate Roles of the Judiciary in the Global Order at the University of Oslo.

\section{Declarations}

Ethics The study complies with the Norwegian National Committee for Research Ethics in the Social Sciences and the Humanities (NESH) and has been approved by the Norwegian Centre for Data Research (NSD).

Conflict of Interest The author declares no competing interests.

Open Access This article is licensed under a Creative Commons Attribution 4.0 International License, which permits use, sharing, adaptation, distribution and reproduction in any medium or format, as long as you give appropriate credit to the original author(s) and the source, provide a link to the Creative Commons licence, and indicate if changes were made. The images or other third party material in this article are included in the article's Creative Commons licence, unless indicated otherwise in a credit line to the material. If material is not included in the article's Creative Commons licence and your intended use is not permitted by statutory regulation or exceeds the permitted use, you will need to obtain permission directly from the copyright holder. To view a copy of this licence, visit http://creativecommons.org/licenses/by/4.0/. 


\section{References}

ACLU. (2008) New documents reveal unlawful Guantanamo procedures were also applied on American soil. https://www.aclu.org/press-releases/new-documents-reveal-unlawful-guantanamo-procedures-were-alsoapplied-american-soil: American Civil Liberies Union.

Agamben G. (2005) State of exception: University of Chicago Press.

Alston P. (2017) The populist challenge to human rights. Journal of Human Rights Practice 9: 1-15.

Amnesty. (2002) United States of America: Beyond the law: Update to Amnesty International's April Memorandum to the US government on the rights of the detainees held in custody. AMR 51/184/2002. https://www.amnesty.org/en/documents/AMR51/184/2002/en/: Amnesty International.

Aradau C. (2007) Law transformed: Guantanamo and the 'other'exception. Third World Quarterly 28: 489501 .

Barnett M. (2005) Humanitarianism transformed. Perspectives on politics: 723-740.

Benford RD and Snow DA. (2000) Framing processes and social movements: An overview and assessment. Annual review of sociology 26: 611-639.

Bravin J. (2013) The Terror Courts: Rough Justice at Guantanamo Bay: Yale University Press.

Brigg M and George N. (2020) Emplacing the spatial turn in peace and conflict studies. Cooperation and Conflict 55: 409-420.

Butler J. (2002) Guantanamo Limbo: International law offers too little protection for prisoners of the new war. New York: The Nation, 20-23.

Carpenter RC and Jose B. (2012) Transnational issue networks in real and virtual space: the case of women, peace and security. Global Networks 12: 525-543.

Cole D. (2016) Engines of liberty: The power of citizen activists to make constitutional law: Basic Books.

Collinson S and Elhawary S. (2012) Humanitarian space: a review of trends and issues: Humanitarian Policy Group, Overseas Development Institute London.

Davies M. (2014) States of compliance?: Global human rights treaties and ASEAN member states. Journal of Human Rights 13: 414-433.

Denbeaux M, Denbeaux JW and Gregorek JW. (2006) Report on Guantanamo Detainees: A Profile of 517 Detainees Through Analysis of Department of Defense Data (February 2006). Seton Hall Public Law Research Paper: 1-28.

Denbeaux MP and Hafetz J. (2009) The Guantanamo lawyers: Inside a prison outside the law: NYU Press.

Dieckhoff M. (2020) Reconsidering the humanitarian space: Complex interdependence between humanitarian and peace negotiations in Syria. Contemporary Security Policy: 1-23.

Dixon P. (2019) 'Endless wars of altruism'? Human rights, humanitarianism and the Syrian war. The International Journal of Human Rights 23: 819-842.

Douzinas C. (2007) Human rights and empire: the political philosophy of cosmopolitanism, Abingdon: Routledge-Cavendish.

Dudai R. (2017) Human rights in the populist era: Mourn then (re) organize. Journal of Human Rights Practice 9: 16-21.

Duffy H. (2015) The'War on Terror'and the Framework of International Law: Cambridge University Press.

Ewick P and Silbey SS. (1998) The common place of law: Stories from everyday life, Chicago: University of Chicago Press.

Fassin D and Pandolfi M. (2010) Contemporary states of emergency: the politics of military and humanitarian interventions: Zone Books New York.

Glasius M. (2002) Expertise in the Cause of Justice: Global Civil Society Influence on the Statute for an International Criminal Court. In: Glasius M, Kaldor M and Anheier HK (eds) Global Civil Society. Oxford University Press, 137-168.

Greenberg KJ. (2009) The Least Worst Place: Guantanamo's first 100 days: Oxford University Press.

Gregory D. (2006) The black flag: Guantánamo Bay and the space of exception. Geografiska Annaler: Series B, Human Geography 88: 405-427.

Gregory D. (2010) Vanishing points: Law, violence, and exception in the global war prison. Terror and the Postcolonial: 55-98.

Gusterson H. (1997) Studying up revisited. PoLAR 20: 114.

Hafetz J. (2013) Diminishing the Value of War Crimes Prosecutions: A View of the Guantanamo Military Commissions from the Perspective of International Criminal Law. Cambridge International Law Journal 2: $800-824$.

Hafner-Burton EM. (2008) Sticks and stones: Naming and shaming the human rights enforcement problem. International organization: 689-716. 
Haire SM. (2020) No Way Out: The Current Military Commissions Mess at Guantanamo. Seton Hall Law Review 50: 7.

Honigsberg PJ. (2019) A Place Outside the Law: Forgotten Voices from Guantanamo: Beacon Press.

HRW. (2008) Lawless in Guantanamo. https://www.hrw.org/news/2008/05/02/lawless-guantanamo: Human Rights Watch.

Hubert D and Brassard-Boudreau C. (2010) Shrinking humanitarian space? Trends and prospects on security and access. Journal of Humanitarian Assistance 24.

Ito S. (2008) At Guantánamo, Iguanas Have Rights. Detainees, Not So Much. In: ACLU (ed). https://www. aclu.org/blog/national-security/guantanamo-iguanas-have-rights-detainees-not-so-much: American Civil Liberties Union.

Johns F. (2005) Guantanamo Bay and the Annihilation of the Exception. European Journal of International Law 16: 613-635.

Johns F. (2013) Non-legality in international law: unruly law: Cambridge University Press.

Kaplan A. (2005) Where is Guantanamo? American Quarterly 57: 831-858.

Keck ME and Sikkink K. (1998) Activists Beyond Borders: Advocacy Networks in International Politics, New York: Cornell University Press.

Kelly T. (2019) The Struggle Against Torture: Challenges, Assumptions and New Directions. Journal of Human Rights Practice 11: 324-333.

Lohne K. (2017a) Twist of fate: Terror, torture and justice in the 9/11 trial in Guantanamo Bay. Opendemocracy.net. 12 February 2017.

Lohne K. (2017b) Global civil society, the ICC, and legitimacy in international criminal justice. In Hayashi N and Bailliet CM (eds) The legitimacy of international criminal tribunals. Cambridge University Press

Lohne K. (2018) NGOs for international justice: Criminal or victims' justice. In: Ulfstein G and Føllesdal A (eds) The Judicialization of International Law. Oxford University Press

Lohne K. (2019) Advocates of humanity: Human rights NGOs in international criminal justice: Oxford University Press.

Massey D. (1994) Space, place and gender, Cambridge: Polity Press.

McCall-Smith KL. (2020) Torture and the Right to Fair Trial in the 9/11 Military Commissions. Edinburgh School of Law Research Paper.

Moorehead C. (1998) Dunant's dream: War, Switzerland and the history of the Red Cross.

Mukherjee A. (2011) The fact-finding missions of the special rapporteur on torture. The International Journal of Human Rights 15: 265-285.

Nowak M. (2009) Fact-Finding on Torture and Ill-Treatment and Conditions of Detention. Journal of Human Rights Practice 1: 101-119.

Ratner M, Ray E and Lewis A. (2004) Guantanamo: What the world should know: Chelsea Green Publishing.

Reid-Henry S. (2007) Exceptional sovereignty? Guantánamo Bay and the re-colonial present. Antipode 39: 627-648.

Rieff D. (2003) A bed for the night: Humanitarianism in crisis: Simon and Schuster.

Rosenberg C. (2016) Guantanamo Bay - The Pentagon's Alcatraz of the Caribbean: The Miami Herald and el Nuevo Herald.

Sandvik KB. (2016) The humanitarian cyberspace: shrinking space or an expanding frontier? Third World Quarterly 37: 17-32.

Schmitt C. (2005 [1922]) Political theology: Four chapters on the concept of sovereignty: University of Chicago Press.

Scholte JA. (2018) Civil society and NGOs. In: Weiss TG and Wilkonson R (eds) International Organization and Global Governance. Second Edition ed. Abingdon: Routledge.

Slim H. (2004) With or against? Humanitarian agencies and coalition counter-insurgency. Refugee Survey Quarterly 23: 34-47.

Steyn J. (2004) Guantanamo Bay: the legal black hole. International \& Comparative Law Quarterly 53: 1-15.

Walters W and Luscombe A. (2019) Secrecy research amidst the ruins of an atomic weapons research facility1. In: Goede Md, Bosma E and Pallister-Wilkins P (eds) Secrecy and Methods in Security Research: A Guide to Qualitative Fieldwork. London and New York: Routledge.

Publisher's Note Springer Nature remains neutral with regard to jurisdictional claims in published maps and institutional affiliations. 